\title{
The effects of fragmentation on the genetic structure of Theobroma speciosum (Malvaceae) populations in Mato Grosso, Brazil
}

\author{
Juliana de Freitas Encinas Dardengo, Ana Aparecida Bandini Rossi \& Tatiane Lemes Varella \\ Laboratório de Genética Vegetal e Biologia Molecular, Rede Bionorte, Faculdade de Ciências Biológicas e Agrárias, \\ Universidade do Estado de Mato Grosso, Campus de Alta Floresta, Residencial Flamboyant, 78.580-000, Alta \\ Floresta, Mato Grosso, Brazil; ju_kk@hotmail.com, anabanrossi@gmail.com, tativarella@hotmail.com
}

\section{Received 02-VI-2017. Corrected 20-X-2017. Accepted 13-XI-2017.}

\begin{abstract}
Native Theobroma species, such as cacauhy, are losing their habitat due to the intense forest fragmentation in the Amazon region, and preserving their genetic diversity has been the focus of many conservation programs. The aim of the present study is to assess whether fragmentation and habitat reduction affect its genetic structure and lead to genetic diversity losses in natural Theobroma speciosum populations. The study was conducted in two Mato Grosso State (Brazil) locations: Apiacás and Alta Floresta counties. Juruena National Park (JNP) in Apiacás County holds a natural T. speciosum population that has not suffered anthropic influences. A population composed of individuals from three anthropized urban forest parks (UF) in Alta Floresta County was analyzed for comparison. The leaves of $75 \mathrm{~T}$. speciosum individuals distributed in the urban forest fragments and of 100 individuals found in the Juruena National Park were sampled. All nine microsatellite loci showed high polymorphism levels between categories (adults and sub-adults), in both populations. The sub-adult individuals of the fragmented area had a higher value (0.71), and the preserved population, the same value (0.69). The analysis of molecular variance showed $83 \%$ genetic diversity within categories; $16 \%$, between populations; and only $1 \%$, between categories. Although the effects were small, a persistent fragmentation process can increase inbreeding and facilitate genetic drift, leading T. speciosum populations to inbreeding depression and loss of diversity. Rev. Biol. Trop. 66(1): 218-226. Epub 2018 March 01.
\end{abstract}

Key words: genetic variability, cacauhy, inbreeding, Amazon, anthropic influence, microsatellite.

The Amazon is an extraordinary supplier of natural resources to the Brazilian and world populations. The sustainable use of these resources and the lack of biological knowledge about most of the Amazonian flora species are challenges for future generations (Silva et al., 2015).

Theobroma speciosum Willd. ex Spreng. (cacauhy) is native to the Amazonian region and it is distributed in primary forests of unflooded lands. This species, although little known, is important because it represents a possible source of resistance among most of the economically relevant species belonging to genus Theobroma (Silva et al., 2015).

Native Theobroma species, such as cacauhy, are losing their habitat due to the intense forest fragmentation in the Amazon, and thus preserving the genetic diversity has been the main goal of most conservation programs focused on preserving the gene of interest and on allowing species variability maintenance at genetic level (Bekessy et al., 2002).

Forest fragmentation decreases the number of individuals in a given population and, consequently, favors genetic variation losses. Genetic drift is the measured gene frequency of these individuals. In the short term, apart from the gene frequency of the original population, including the allele losses, genetic drift may occur in this small population. It is likely to have increased inbreeding in the longterm due to the increased inbreeding and mating probability between related individuals (Sebbenn, 
Seoane, Kageyama, \& Vencovsky, 2000). The reproductive success of fragmented populations can be impaired by the smaller number of floral visitors, which may be caused by pollinator richness and abundance decrease (Colevatti, Lima, Soares, \& Telles, 2010).

Studying the genetic variation of a given species in a natural population involves two issues: quantifying the variability levels within populations, and characterizing the genetic structure level of these populations (Hamrick, 1983). According to Hardy-Weinberg, and to the fixation index (f), the intrapopulation genetic variability has been quantified through the number of alleles per locus (A), the percentage of polymorphic loci (P) and the observed (Ho) and expected (He) heterozygosity (Ho) (Hamrick, 1983).

The second issue concerns the way genetic variability splits between, and within, populations; in other words, it concerns the genetic structure level of the population. The genetic structure refers to the heterogeneous distribution (non-random) of alleles and genotypes in space and time. Such distribution results from the action of evolutionary forces such as mutation, migration, selection and genetic drift within each species and population (Hamrick, 1982).

The lack of information concerning the genetic consequences of forest fragmentation in natural Theobroma speciosum populations led to the aim of the present study, which was to assess whether fragmentation and habitat reduction affect the genetic structure and cause genetic diversity losses in natural $T$. speciosum populations, distributed in areas under different fragmentation background and intensity.

\section{MATERIALS AND METHODS}

Study sites: The study was conducted in two locations in Mato Grosso State, Brazil: Alta Floresta and Apiacás counties. The ombrophilous forest is the prevailing vegetation type in the sites. The climate is equatorial (warm and humid) and the mean annual temperature is $24{ }^{\circ} \mathrm{C}$, the highest mean temperature reaches $40{ }^{\circ} \mathrm{C}$. Summers are sunny and winters are clear and dry.

T. speciosum height ranges from 8-14 m, it presents a long stem, a thin and narrow canopy, and $20-40 \mathrm{~cm}$ long and $7-17 \mathrm{~cm}$ wide leaves (Fig. 1 A). The almonds of its berry-type fruits present yellowish color a tripe stage and can be used in soft drinks and chocolate production (Fig. 1 A). The plant can be successfully used for landscaping due to its exuberant inflorescence along the stem (Fig. 1 B, Fig. 1C and Fig. 1D) (Lorenzi, 1998).

One natural $T$. speciosum population, not subjected to anthropic influence, distributed in Juruena National Park (JNP), Apiacás County $\left(57^{\circ} 27^{\prime} 1^{\prime \prime} \mathrm{S}, 9^{\circ} 32^{\prime} 38^{\prime \prime} \mathrm{W}\right)$, was analyzed (Fig. 2). One population formed by individuals from three urban fragments (C/E Park, 9.19 ha (56 7'35" S, 9०54'20" W); J Park, 7.38 ha (56 4'22" S, 9०53'32"'W); and Zoobotanical Park, 17.6 ha (56 5'24' S, 9॰52'33' W) in Alta Floresta County was also analyzed (Fig. 2).

\section{Sampling process and DNA extraction:} Two leaves from each of the $25 \mathrm{~T}$. speciosum individuals were sampled in each urban fragment for a total of 75 individuals. One hundred individuals were sampled in Juruena National Park. All individuals showing DBH (diameter at breast height) bigger than $1 \mathrm{~cm}$ were sampled and georeferenced (GPS Garmin Etrex ${ }^{\circledR}$ ).

Plants from each population, belonging to two categories, sub-adults $(\mathrm{DBH} \leq 05 \mathrm{~cm})$ and adults (DBH $>05 \mathrm{~cm}$ ) (Dardengo, Rossi, Silva, Silva, \& Sebbenn, 2016), were sampled in order to have their genetic variability, as well as the structure of their individuals studied in different development stages, at each anthropic action level. The total genomic DNA was extracted through the cetyltrimethylammonium bromide method by Doyle and Doyle (1990).

Primer selection and amplification through PCR: A total of 23 microsatellite loci (SSR), previously isolated and characterized according to Lanaud et al. (1999), were tested in initial PCR amplification using one T. speciosum plant chosen after DNA quantification. 


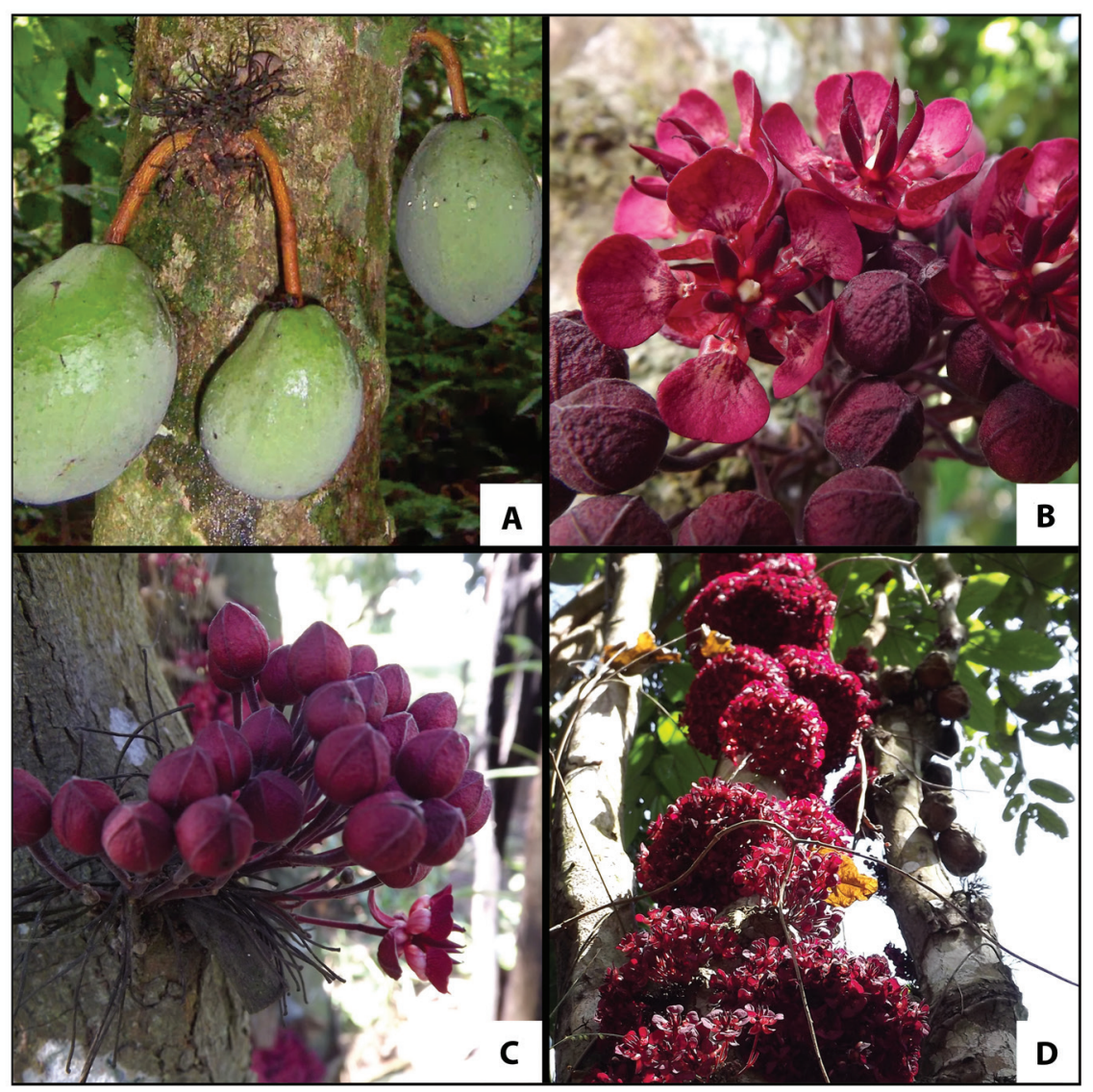

Fig. 1. Morphologic aspects of Theobroma speciosum. A) Tree with fruits. B) Inflorescence, open flowers. C) Inflorescence, flower buds. D) Tree with fruits and inflorescence.

Nine of the twenty-three tested loci were selected for species genetic diversity analysis.

The amplification was conducted according to the protocol by Lanaud et al. (1999), with some modifications. It comprised an initial denaturation cycle at $94{ }^{\circ} \mathrm{C}$, for $4 \mathrm{~min}$, which was followed by 32 cycles at $94{ }^{\circ} \mathrm{C}$, for 30 seconds at $46{ }^{\circ} \mathrm{C}$, or at $51^{\circ} \mathrm{C}$ (depending on the applied primer), for $1 \mathrm{~min}$, and at $72^{\circ} \mathrm{C}$, for $1 \mathrm{~min}$ as well as by a final extension cycle at $72{ }^{\circ} \mathrm{C}$, for $5 \mathrm{~min}$.

The genetic diversity of adult and sub-adult individuals was estimated based on the total number of alleles $(k)$, on the highest allelic frequency $(\mathrm{Fa})$, on the observed $\left(\mathrm{H}_{\mathrm{o}}\right)$ and expected $(\mathrm{He})$ heterozygosity (at Hardy-Weinberg equilibrium in each locus and across all loci), and on the polymorphism information content (PIC), in order to verify the quality of the used loci. The analysis of variance was conducted in the Genes software (Cruz, 1997). The inbreeding level between the sampled individuals was estimated based on the fixation index $(F)$, according to the method by Weir and Cockerham (1984). All the analyses were run in the Power Marker software, version 3.25. The deviation from zero of each locus, was estimated through the Hardy-Weinberg equilibrium proportions measured in the Cervus software (Kalinowski, Taper, \& Marshall, 2007).

The molecular genetic structure was quantified through the analysis of molecular 

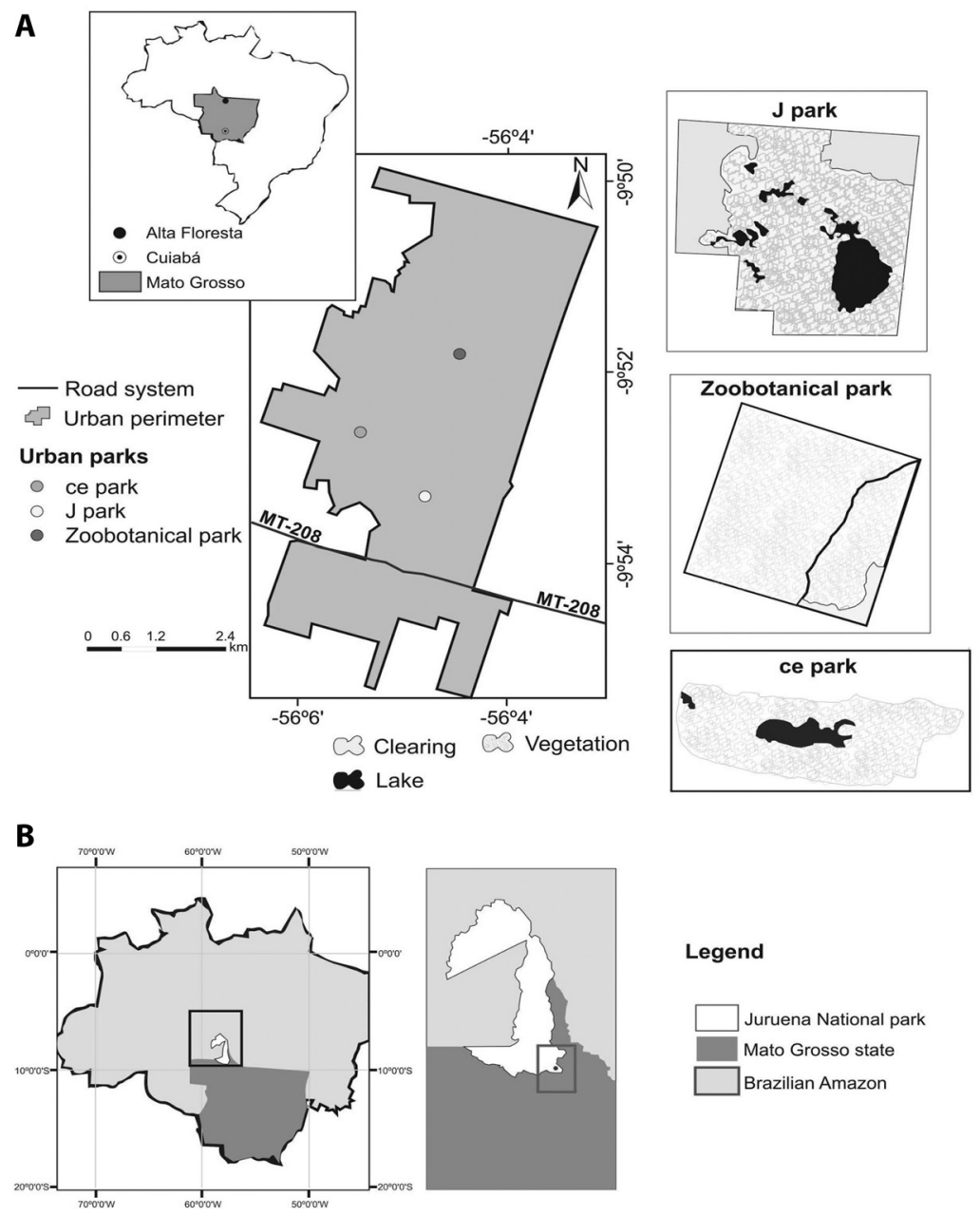

Legend

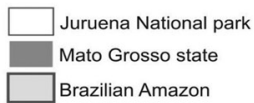

Fig. 2. A) Alta Floresta County location and each of the urban forest parks under study in Southern Amazon, Brazil. B) Location of the Juruena National Park (JNP) sampling, Southern Amazon, Brazil.

variance (AMOVA) based on the RST statistical method. The total genetic diversity was analyzed in the GenAIEx 6.5® software, at three distinct hierarchical levels, namely: the difference between populations between categories (sub-adult and adult), and between individuals within categories. The genetic structure between populations (category) was also quantified in the PopGene1.32 software through genetic distance estimates and the RST statistical genetic identity by Nei (1978).

\section{RESULTS}

Intrapopulation genetic variability: All nine microsatellite loci have shown high polymorphism levels between categories in the two populations no locus deviated from the Hardy-Weinberg equilibrium proportions. The least varying locus (mTcCIR7) and the most varying one (mTcCIR10) have shown 4 and 13 alleles, respectively. Forty-three individuals per category were analyzed in each population, on average, revealing the total of 141 alleles in the 
samples. The estimated mean genetic diversity parameter values were very high and homogeneous between categories (Table 1). The number of alleles per locus (k) ranged from 7.88 to 8.67; the expected heterozygosity $(\mathrm{He})$, from 0.80 to 0.97 ; and the observed heterozygosity (Ho), from 0.24 to 0.26 . Adults and sub-adults in the JNP population presented the same total number of alleles (78); however, adults had more alleles (72) than sub-adults (71) in the population from the urban parks, the adults had 8 unique alleles and the sub-adults, 7.

Although there were no significant differences between values, the contrasting heterozygosity (Ho) between the two populations evidenced higher heterozygosity (Ho) in adults and sub-adults from the JNP, and lower heterozygosity (Ho) in both categories from the urban parks, fact that reveals the inbreeding process in fragmented populations (Table 1). The subadult individuals in the fragmented population (UF) have shown higher $F$ value $(0.71)$ in the mean population, whereas the preserved population (JNP) presented the same values (0.69). All loci had high polymorphic information content (PIC), the average per category ranged from 0.74 (sub-adults in urban fragments) to 0.82 (sub-adults in JNP) (Table 1).

The allelic frequency analysis has shown that all populations presented unique alleles in the two categories of the herein studied plants.
The two groups have shown 09 and 08 unique alleles in the adult and sub-adult individuals divided in the two populations, respectively. Since the sub-adult individuals in JPN have presented the lowest mean allelic frequency value $(0.25)$, they have also presented the best allelic frequency uniformity. The sub-adults from the parks have shown the highest mean allele frequency (0.34), thus evidencing the dominance of the alleles.

Genetic structure: The molecular variance analysis has shown that most genetic diversities are found within the adult and subadult categories ( $83 \%$ ), whereas $16 \%$ of these diversities are found between populations only $1 \%$ of them are found between categories (Table 2).

Table 3 shows that the categories within each T. speciosum population are more genetically similar, fact that evidences the link between them. It is worth highlighting that the adults in the sampled populations are genetically closer to each other than the sub-adults.

\section{DISCUSSION}

The nine microsatellite loci used in the current study have shown high molecular genetic variation levels, thus confirming the

TABLE 1

Genetic diversity and inbreeding in microsatellite loci of adult and sub-adult Theobroma speciosum plants in Juruena National Park (JNP) and in urban fragments (UF)

\begin{tabular}{|c|c|c|c|c|c|c|c|c|c|c|c|c|}
\hline \multirow{3}{*}{$\begin{array}{l}\text { Categories/ } \\
\text { Populations }\end{array}$} & \multicolumn{6}{|c|}{ Adults } & \multicolumn{6}{|c|}{ Sub-adults } \\
\hline & \multicolumn{3}{|c|}{ JNP } & \multicolumn{3}{|c|}{ UF } & \multicolumn{3}{|c|}{ JNP } & \multicolumn{3}{|c|}{ UF } \\
\hline & Mean & SE & Total & Mean & SE & Total & Mean & SE & Total & Mean & SE & Total \\
\hline K & $8.67^{£}$ & \pm 2.66 & 78 & $8.0^{f}$ & \pm 3.66 & 72 & $8.67^{\mathfrak{f}}$ & \pm 2.67 & 78 & $7.88^{\mathfrak{f}}$ & \pm 3.55 & 71 \\
\hline$F a$ & 0.26 & \pm 0.13 & - & 0.28 & \pm 0.10 & - & 0.25 & \pm 0.08 & - & 0.34 & \pm 0.19 & - \\
\hline Ho & $0.26^{\mathrm{ns}}$ & \pm 0.16 & - & $0.24^{\mathrm{ns}}$ & \pm 0.25 & - & $0.26^{\mathrm{ns}}$ & \pm 0.17 & - & $0.24^{\mathrm{ns}}$ & \pm 0.21 & - \\
\hline He & $0.80^{\mathrm{ns}}$ & \pm 0.13 & - & $0.87^{\mathrm{ns}}$ & \pm 0.04 & - & $0.84^{\mathrm{ns}}$ & \pm 0.09 & - & $0.86^{\mathrm{ns}}$ & \pm 0.04 & - \\
\hline$F$ & $0.69 *$ & \pm 0.19 & - & $0.70^{*}$ & \pm 0.28 & - & $0.69 *$ & \pm 0.09 & - & $0.71 *$ & \pm 0.24 & - \\
\hline$P I C$ & 0.81 & \pm 0.09 & - & 0.77 & \pm 0.09 & - & 0.82 & \pm 0.09 & - & 0.74 & \pm 0.17 & - \\
\hline
\end{tabular}

k: Total number of alleles in each locus and in all loci; Fa: higher allelic frequency; Ho: observed heterozygosity; He: expected heterozygosity in Hardy-Weinberg equilibrium; F: fixation index. PIC: Polymorphic Information Content. ${ }^{n s}$ not significance tested through analysis of variance; * $\mathrm{P}<0.05 . £=$ mean number of alleles in the loci (A). 
TABLE 2

Analysis of molecular variance (AMOVA) in adult and subadult Theobroma speciosum trees in Juruena National Park and in urban forest parks, using the 9 SSR loci

\begin{tabular}{lccccc}
$\quad$ Variation Source & DF & SS & CV & TV (\%) & P value \\
Between populations & 1 & 2431906.063 & 2431906.063 & 16 & $<0.001$ \\
Between Categories & 2 & 335048.500 & 167524.250 & 1 & \\
Within categories & 346 & 24251384.911 & 70090.708 & 83 & \\
Total & 349 & 27018339.474 & 2431906.063 & 100 & \\
\hline
\end{tabular}

$\mathrm{DF}=$ degrees of freedom; $\mathrm{SS}=$ sum of the squares; $\mathrm{CV}=$ coefficient of variation; $\mathrm{TV}=$ total variation; $\mathrm{P}=$ chances of a variance component higher than the values observed by chance. The probabilities were calculated using 1000 random permutations.

TABLE 3

Measures of Genetic Identity and Distance Genetics of adult and sub-adult Theobroma speciosum trees in Juruena National Park (JPN) and in urban forest parks (UF) unbiased by Nei (1978), using the 9 SSR loci

\begin{tabular}{lcccc}
\multicolumn{1}{c}{ Categories } & Adults-JPN & Sub-adults-JPN & Adults-UF & Sub-adults-UF \\
Adults-JPN & $* * * * *$ & 0.9162 & 0.1756 & 0.1582 \\
Subadults-JPN & 0.0876 & $* * * * *$ & 0.1929 & 0.1741 \\
Adults-UF & 1.7397 & 1.6456 & $* * * * *$ & 0.9325 \\
Subadults-UF & 1.8438 & 1.7481 & 0.0698 & $* * * * *$ \\
\hline
\end{tabular}

Values above the diagonal genetics identity and below the diagonal genetic distance.

high genetic information content in these markers presented in other studies about the genetic parameters of Theobroma species populations, as described by Lemes, Martiniano, Reis, Faria, \& Gribel (2007). All loci in the T. speciosum species have shown high polymorphic information content (PIC). According to Botstein (1980), markers presenting PIC above 0.50 are very informative those presenting PIC between 0.25 and 0.50 are moderately informative, and those presenting PIC below 0.25 are slightly informative.

The number of unique alleles in adult individuals suggests the occurrence of genetic drift, i.e., the elimination of young individuals who have alleles found in adult individuals. Not all individuals are able to have offspring; however, the number of unique alleles in subadult individuals suggests lack of gene flow or the presence of parental in the population (Carvalho et al., 2010).

The maintenance of heterozygosity levels over generations in the absence of gene flow depends on the effective population size $(\mathrm{Ne})$, on the number of elapsed generations $(t)$, and on the initial heterozygosity (Ho), so that $\mathrm{Ht}$ $=(1-1 / 2 \mathrm{NE})$ tHo to constant Ne. Thus, it appears that the significant changes in the heterozygosity levels of some generations are only possible through drastic effective size reduction; otherwise, a little change can be observed. So far, as the fragmentation in urban park areas is recent (less than 40 years), it can be stated that the genetic diversity levels were not affected by the fragmentation process when they were compared to the genetic diversity level shown by plants from the Juruena National Park, which is ruled and supervised by ICMBio.

Young, Merriam \& Warwick (1993), in their study about the effects of genetic drift on the remaining Acer saccharum populations, have compared eight individuals presenting reduced size to eight individuals from large untouched populations. They found that the remaining populations (smaller than 96 trees) 
have shown no signs of genetic variation reduction; thus, suggesting that the effect of genetic drift in a period of 150-200 years (2-3 generations) is small after forest fragmentation. Similar results were found in the present study, fact that corroborates the assumption that the intense fragmentation process in the UF did not reduce the allelic frequency in T. speciosum.

The gene flow from neighboring populations may have played an important role in maintaining the diversity levels of fragmented populations (Young, Boyle, \& Brown, 1996). The presence of $T$. speciosum populations observed in nearby-forest fragmented populations may have helped keeping the diversity levels of these populations; however, it is likely that these diverse levels may decrease in the course of several generations.

The mean fixation index $(\mathrm{F})$ between loci in the fragmented populations was slightly higher than that of the population in the JNP. It suggests Hardy-Weinberg equilibrium proportion deviations due to the excess of homozygotes, which was probably caused by inbreeding.

The increased selfing and bi-parental crosses are the consequences of the reduced number of reproductive individuals, which leads to inbreeding in future generations (Aldrichet, Hamrick, Chavarriaga, \& Kochert, 1998). The HWE deviations imply the reproductive division of the population in groups that have a certain degree of relation. The division is possibly associated with family structures, within the population or with preferential mating, as it was observed in the studied populations.

Another explanation for the high inbreeding values lies on the presence of null alleles, because it increases the number of homozygous individuals, since just one of the alleles amplifies itself in cases of null allele in heterozygous plant (Nybom, 2004).

Sebbenn et al. (2000) have found a remarkable inbreeding level increase in an exploited Tabebuia cassinoides population due to the increased selfing rates. In a similar study comparing natural and exploited Shorea megistophylla populations, Murawskiet, Dayanandan \& Bawa (1994) have found differences in the inbreeding levels of different populations, as well as changes such as increased selfing in the reproductive behavior of exploited populations. However, Theobroma speciosum is a self-incompatible species (Souza \& Venturieri, 2010) that, according to Silva and Martins (2004), presented adequate pollination syndrome by Diptera saprophages. Drosophila $\mathrm{sp}$. is its major pollinator, so the fixation index presented in this study can only be justified by biparental inbreeding.

The AMOVA results suggest that the genetic differentiation is greater in the intrapopulation component than in the interpopulation one. The values are consistent with those found in other tropical allogamous species. Silva et al. (2016) have reported that $34.91 \%$ of the genetic variability in Theobroma grandiflorum populations happens between crops. Rossi et al. (2014) have analyzed three natural Mauritia flexuosa populations and observed that $15.9 \%$ of the total genetic variation happens between populations. However, Giustina et al. (2014) and Rivas et al. (2013) have studied natural Theobroma speciosum and Theobroma subincanum populations, respectively, and found higher interpopulation genetic differentiation.

The genetic distance difference between sub-adults and between adults may result from the recent fragmentation of the study site. According to Rosa, Perin \& Rosa (2003), the first settlers arrived in the area where today is downtown Alta Floresta, MT, in 1976; nowadays, the site holds the UF population. Therefore, the cover-habitat reduction process faced by the forest in the herein studied site has taken place in less than 40 years ago; thus, it appears that fragmentation started to get more intense in the generation sampled in the sub-adult category, since the sampled adults were located in the pre-fragmentation habitat.

The genetic information of the nine microsatellite loci have shown that the fragmentation process has so far caused little changes in the diversity levels and in the genetic structure of $T$. speciosum populations. However, the reduced number of individuals able to reproduce in the population, has resulted in possible 
mating changes, fact that has led to increased inbreeding levels, mainly in the sub-adults of fragmented populations.

Although the forest fragmentation effects were small, the fragmentation process persistence may further increase the inbreeding levels and facilitate the genetic drift action. These effects may lead the species to inbreeding depression, diversity losses, as well as to changes in the genetic structure of the populations in the course of several generations. Therefore, researches and actions focused on preserving these sites are necessary to avoid genetic diversity losses to keep on happening.

\section{ACKNOWLEDGMENTS}

The authors would like to thank BIONORTE - MT (Projeto Conhecimento, Uso Sustentável e Bioprospecção da Biodiversidade na Amazônia Meridional - Processo: 554330/2010-5), PPBio (Projeto Inventário, conservação e valoração de alternativas sustentáveis do uso da Biodiversidade na Amazônia Meridional-Processo: 558319/2009-2) and CAPES for their financial support. We also thank Good Deal Consultoria Linguística for editing the manuscript.

\section{RESUMEN}

Efectos de la fragmentación en la estructura genética de las poblaciones de Theobroma speciosum (Malvaceae) en Mato Grosso, Brazil. Las especies nativas de Theobroma, como cacauhy, están perdiendo su hábitat debido a la intensa fragmentación forestal en la región amazónica. Por lo tanto, preservar la diversidad genética ha sido el objetivo principal de la mayoría de los programas de conservación. El objetivo de este estudio fue evaluar si la fragmentación y la reducción del hábitat afectan la estructura genética y causan la pérdida de diversidad genética en poblaciones naturales de Theobroma speciosum. El estudio se realizó en dos localidades del estado de Mato Grosso, Mato Grosso, Brasil, en el municipio de Apiacás, se consideró una población natural de $T$. speciosum sin influencia antrópica, ubicada en el Parque Nacional Juruena (JNP) y en el municipio De Alta Floresta se analizó una población compuesta por individuos de tres parques forestales urbanos antropizados (UF). Fueron muestreadas las hojas de 75 individuos de $T$. speciosum de los fragmentos de bosque urbano y 100 individuos del
Parque Nacional de Juruena. Los nueve loci microsatélites mostraron altos niveles de polimorfismo entre las categorías (adultos y sub-adultos) en ambas poblaciones. En la población media, los individuos sub-adultos fragmentados de la población (UF) mostraron un mayor valor de f (0.71), mientras que la categoría de población preservada (JNP) presentó valores iguales entre sí (0.69). El análisis de la varianza molecular mostró que la mayoría de la diversidad genética está dentro de las categorías ( $83 \%)$, mientras que el $16 \%$ se encuentra entre la población y sólo el $1 \%$ entre las categorías. Aunque los efectos fueron pequeños, si el proceso de fragmentación persistente puede aumentar los niveles de endogamia y facilitar la acción de la deriva genética. En el curso de varias generaciones, estos efectos pueden conducir a la depresión endogámica, la pérdida de diversidad y la alteración de la estructura genética de poblaciones de T. speciosum.

Palabras clave: variabilidad genética, cacaui, endogamia, Amazonia, influencia antrópica, microsatélite.

\section{REFERENCES}

Aldrich, R. P., Hamrick, J. L., Chavarriaga, P., \& Kochert, G. (1998). Microsatellite analysis of demographic genetic structure in fragmented populations of the tropical tree Symphonia globulifera. Molecular Eco$\log y$, 7, 933-944.

Bekessy, S. A., Allnutt T. R., Premoli A. C., \& Lara A. (2002). Genetic variation in the vulnerable and endemic Monkey Puzzle tree, detected using RAPDs. Heredity, 88, 243-249.

Botstein, D. (1980). Construction of a genetic linkage map in man using restriction fragment length polymorphism. American Journal of Human Genetics, 32, 314-331.

Carvalho, A. C. M., Freitas, M. L. M., Moraes, S. M. B., Moraes, M. L. T., Stranghetti, V., Alzete-Martins, A. L., \& Sebbenn, A. M. (2010). Diversidade genética, endogamia e fluxo gênico em pequena população fragmentada de Copaifera langsdorffii. Revista Brasileira de Botânica, 33, 599-606.

Colevatti, R. G., Lima, J. S., Soares, T. N., \& Telles, M. P. C. (2010). Spatial Genetic Structure and life history traits in Cerrado tree species: Inferences for conservation. Natureza \& Conservação, 8(1), 54-59.

Cruz, C. D. (1997). Programa Genes: aplicativo computacional em genética e estatística. Viçosa: Editora UFV.

Dardengo, J. F. E., Rossi, A. A. B., Silva, B. M., Silva, C. J., \& Sebbenn, A. M. (2016). Diversity and spatial genetic structure of a natural population of Theobroma speciosum (Malvaceae) in the Brazilian Amazon. Revista de Biología Tropical, 64(3), 1091-1099. 
Doyle, J. J., \& Doyle, J. L. (1990). Isolation of plant DNA from fresh tissue. Focus, 12, 1315-1321.

Giustina, L. D., Luz, L. N., Vieira, F. S., Rossi, F. S., Soares-Lopes, C. R. A., Pereira, T. N. S., \& Rossi, A. A. B. (2014). Population structure and genetic diversity in natural populations of Theobroma speciosum Willd. ex Spreng (Malvaceae). Genetics and Molecular Research, 13(2), 3510-3519.

Hamrick, J. L. (1982). Plant population genetics and evolution. American Journal of Botany, 69(10), 1685-1693.

Hamrick, J. L. (1983). The distribution of genetic variation within and among natural plant populations. In C.M. Schonewald-Cox, S. M. Chambers, B. Macbryde, W. L. Thomas (Eds.), Genetic and Conservation (pp. 335-348). California: Benjamin/Cummings, Menlo Park.

Kalinowski, S. T., Taper, M. L., \& Marshall, T. C. (2007). Revising how the computer program CERVUS accommodates genotyping error increases success in paternity assignment. Journal of Molecular Ecology, 16(5), 1099-1106.

Lanaud, C., Risterucci, A. M., Pieretti, I., Falque, M., Bouet, A., \& Lagoda, P. J. L. (1999). Isolation and characterization of microsatellites in Theobroma cacao L. Molecular Ecology, 8, 2141-2143.

Lemes, M. R., Martiniano, T. M., Reis, V. M., Faria, C. P., \& Gribel, R. (2007). Cross-amplification and characterization of microsatellite loci for three species of Theobroma (Sterculiaceae) from the Brazilian Amazon. Genetic Resources and Crop Evolution, 54, 1653-1657.

Lorenzi, H. (1998). Árvores Brasileiras: Manual de Identificação e Cultivo de Plantas Arbóreas Nativas do Brasil. São Paulo: Editora Plantarum.

Murawski, D. A, Dayanandan, B., \& Bawa, K. S. (1994). Outcrossing rates of two endemic Shorea species from Sri Lankan tropical rain forests. Biotropica, 26(1), 23-29.

Nei, M. (1978). Estimation of average heterozygosity and genetic distance from a small number of individuals. Genetics, 89, 583-590.

Nybom, H. (2004). Comparison of different nuclear DNA markers for estimating intraspecific genetic diversity in plants. Molecular Ecology, 13, 1143-1155.

Rivas, L. H., Giustina, L. D., Luz, L. N., Karsburg, I. V., Pereira, T. N. S., \& Rossi, A. A. B. (2013). Genetic diversity in natural populations of Theobroma subincanum Mart. in the Brazilian Amazon. Genetics and Molecular Research, 12(4), 4998-5006.

Rosa, R. D., Perin, C. L., \& Rosa, R. D. (2003). Colonizador e colonos: na fronteira da terra o limite dos sonhos de um futuro promissor. Revista do Programa de Ciências Agro-Ambientais, 2(1), 71-82.

Rossi, F. S., Rossi, A. A. B., Dardengo, J. F. E., Brauwers, L. R., Silva, M. L., \& Sebbenn, A. M. (2014). Diversidade genética em populações naturais de Mauritia flexuosa L. f. (Arecaceae) com uso de marcadores ISSR. Scientia Forestalis, 42(104), 631-639.

Sebbenn, A. M., Seoane, C. E. S., Kageyama, P. Y., \& Vencovsky, R. (2000). Effects of the management on the genetic structure of caixeta (Tabebuia cassinoides) populations. Scientia Forestalis, 58, 127-143.

Silva, A. R., \& Martins, M. B. (2004). Anew anthophilic species of Drosophila Fallén belonging to the bromeliae group of species (Diptera, Drosophilidae). Revista Brasileira de Zoologia, 21, 435-437.

Silva, B. M., Rossi, A. A. B., Dardengo, J. F. E., Araujo, V. A. A. C., Rossi, F. S., Oliveira, L. O., \& Clarindo, W. R. (2016). Diversidade genética estimada com marcadores entre sequências simples repetidas em cultivos comerciais de Cupuaçuzeiro. Ciência Rural, 46(1), 108-113.

Silva, B. M., Rossi, A. A. B., Dardengo, J. F. E., Silva, C. R., Silva, I. V., Silva, M. L., \& Silva, C. J. (2015). Genetic structure of natural populations of Theobro$m a$ in the Juruena National Park, Mato Grosso State, Brazil. Genetics and Molecular Research, 14(3), 10365-10375.

Souza, M. S., \& Venturieri, G. A. (2010). Floral biology of cacauhy (Theobroma speciosum - Malvaceae). Brazilian Archives of Biology and Technology, 53, 861-872.

Weir, B. S., \& Cockerham, C. C. (1984). Estimating F-statistics for the analysis of population structure. Evolution, 38, 1358-1370.

Young, A. G., Boyle, T., \& Brown, T. (1996). The population genetic consequences of habitat fragmentation for plants. Tree, 11(10), 413-418.

Young, A. G., Merriam, H. G., \& Warwick, S. I. (1993). The effects of forest fragmentation on genetic variation in Acer saccharum Marsh. (sugar maple) populations. Heredity, 71, 277-289. 